\title{
Identifikasi Staphylococcus aureus dan Uji Sensitivitas terhadap Antibiotik dari Sampel Darah Pasien Sepsis di RSUD Dr. Moewardi
}

\author{
Staphylococcus aureus Identification and Sensitivity Test Toward Antibiotic from Sepsis Blood \\ Patient's in Dr. Moewardi General Hospital
}

\author{
Elvira, Nony Puspawati, dan Dionysius Andang Arif Wibawa* \\ Fakultas Ilmu Kesehatan, Universitas Setia Budi \\ *Corresponding author: andangface@yahoo.com
}

\begin{abstract}
ABSTRAK
Sepsis adalah sindroma klinis yang disebabkan oleh infeksi dan ditandai dengan beberapa gejala klinis meliputi hipotermia, leukositosis atau lekopenia, takikardi dan takipnea. Sepsis dapat disebabkan oleh bakteri Gram negatif, bakteri Gram positif, jamur, virus dan parasit. Staphylococcus aureus merupakan salah satu bakteri penyebab sepsis. Terapi utama penderita sepsis yaitu dengan antibiotik. Penelitian ini bertujuan untuk mengetahui adanya Staphylococcus aureus pada sampel darah pasien sepsis di RSUD Dr. Moewardi dan uji sensitivitas terhadap antibiotik.

Penelitian ini menggunakan metode analitik observasional dengan pendekatan Cross-Sectional yaitu pengujian sensitivitas bakteri terhadap antibiotik dengan metode difusi. Penelitian ini dilakukan dengan cara mengisolasi bakteri Staphylococcus aureus dalam sampel darah pasien sepsis di RSUD Dr. Moewardi yang kemudian diuji sensitivitasnya terhadap antibiotik.

Hasil penelitian menunjukkan dari 30 sampel darah pasien sepsis di RSUD Dr. Moewardi didapatkan 16 sampel teridentifikasi positif Staphylococcus aureus (53\%). Hasil uji sensitivitas menunjukkan bahwa Staphylococcus aureus 100\% sensitif terhadap antibiotik vankomisin dan kloramfenikol; 50\% sensitif, 31\% intermediate dan 19\% resisten terhadap antibiotik tetrasiklin; 6\% sensitif, 44\% intermediate dan 50\% resisten terhadap antibiotik eritromisin; 100\% resisten terhadap antibiotik amoksisilin dan linezolid.
\end{abstract}

Kata kunci : sepsis, identifikasi, Staphylococcus aureus, sensitifitas, antibiotic

\section{ABSTRACT}

Sepsis is clinical syndrome which is caused by infection and is marked with several clinical symptoms including hypothermia, leukocytosis or leucopenia, tachycardia and tachypnea. Sepsis can be caused by Gram negative bacteria, Gram positive bacteria, fungus, virus and parasite. One of the bacteria is Staphylococcus aureus. Main therapy for Sepsis patient is by using antibiotic. The aims of this research are to know if there is Staphylococcus aureus bacteria in the Sepsis blood patient's in Dr. Moewardi General Hospital and sensitivity test toward antibiotic.

This research uses observational analytic using Cross-Sectional approach that is testing the bacteria's sensitivity toward antibiotic using diffusion method. This research was conducted by isolating the Staphylococcus aureus bacteria in the sepsis blood patient's in Dr. Moewardi General Hospital. Then, its sensitivity was tested toward antibiotic.

The result of this research shows that from 30 sepsis blood patient samples at Dr. Moewardi General Hospital, 16 of the samples identified positive to Staphylococcus aureus (53\%). The result of the sensitivity test shows that Staphylococcus aureus is 100\% sensitive to vancomycin and chloramphenicol, 50\% sensitive and $31 \%$ intermediate and 19\% resist toward tetracycline, 6\% sensitive, 44\% intermediate and 50\% resist toward eritromisin, 100\% resist toward amoxicillin and linezolid.

Keywords: Sepsis, identification, Staphylococcus aureus, sensitivity, antibiotic.

\section{PENDAHULUAN}

Bakteremia adalah adanya bakteri di dalam darah. Kondisi bakteremia termasuk kondisi yang tidak berbahaya, akan tetapi jika tidak diobati maka akan menjadi infeksi lokal atau sistemik seperti sepsis (Bennet, 2008). Sepsis adalah sindroma klinis yang dicetuskan oleh infeksi dan ditandai dengan beberapa gejala klinis meliputi demam atau hipotermia, leukositosis atau lekopenia, takikardi dan takipnea (Nasronuddin, 2011). 
Sepsis merupakan salah satu penyebab kematian (Hoyert et al., 2001). Kejadian severe sepsis dan septic shock mempunyai hubungan dengan usia lanjut terutama pada orang tua. Kejadian sepsis terjadi di Malaysian Public Hospital dengan angka kematian yang terjadi pada laki-laki $21,58 \%$ dan perempuan $12,16 \%$ (Gillani et al., 2009). Pasien dengan usia $>65$ tahun mempunyai risiko terjadinya sepsis yang meningkat 13 kali lipat. Kasus sepsis di rumah sakit Universitario Dr. Peset, Spanyol mempunyai angka kejadian sepsis paling tinggi terjadi pada pasien dengan umur >70 tahun (Artero et al., 2012).

Sepsis dapat disebabkan oleh bakteri Gram negatif, bakteri Gram positif, jamur, virus, dan parasit (James et al., 2005). Salah satu bakteri penyebab sepsis adalah Staphylococcus aureus (SWAB, 2010). Staphylococcus aureus merupakan bakteri patogen pada manusia karena bakteri ini mampu menginfeksi hampir di semua jaringan dan sistem organ manusia (Wickner dan Schekman, 2005). Bakteri ini secara umum dikenal sebagai bakteri flora normal pada kulit, mulut dan mukosa hidung manusia (Pristianingrum et al., 2012). Penyakit yang ditimbulkan oleh Staphylococcus aureus mulai dari gangguan saluran cerna dan keracunan makanan akibat toksin yang dihasilkannya, infeksi kulit yang ringan, hingga infeksi berat seperti bakteremia, osteomielitis, endokarditis dan infeksi paru yang mengancam jiwa (Brooks et al., 2010).

Terapi utama penderita sepsis yaitu dengan antibiotik. Pemberian antibiotik dalam satu jenis saja tidak dibenarkan pada keadaan sepsis sehingga dianjurkan untuk melakukan kombinasi antibiotik yang rasional yang sesuai dengan hasil kultur (Irawan, 2010). Galur Staphylococcus aureus yang diisolasi dari rumah sakit umumnya telah resisten terhadap berbagai antibiotik yang beredar, kecuali terhadap vankomisin (Radji, 2009).

\section{METODE PENELITIAN}

\section{Alat}

Tabung reaksi steril, spuit $3 \mathrm{cc}$, cawan petri sedang, inkas, incubator, autoclave, mikroskop, penggaris.

\section{Bahan}

Darah pasien sepsis, media VJA (Vogel Johnson Agar), Media BHIB (Brain Heart Infusion Broth) larutan $\mathrm{H}_{2} \mathrm{O}_{2} 3 \%$ (digunakan untuk uji katalase), larutan $\mathrm{NaCl}$ fisiologis $(\mathrm{NaCl}$ 0,9\%), larutan plasma citrat (digunakan untuk uji koagulase), larutan kalium tellurit, larutan Kristal violet (Gram A), larutan lugol iodine (Gram B), larutan etanol 95\% - aseton (Gram C), larutan Safranin (Gram D).

\section{Cara Kerja \\ Isolasi Bakteri}

Sampel darah diambil 1-2 ose lalu digoreskan pada media VJA (Vogel Johnson Agar) kemudian diinkubasi pada suhu $37^{\circ} \mathrm{C}$ selama $24-48$ jam. Hasil positif terdapat bakteri ini maka akan ditandai dengan adanya koloni berwarna hitam dan di sekitar koloni berwarna kuning.

\section{Identifikasi Bakteri \\ Mikroskopis}

Prosedur pewarnaan Gram: (1) Koloni bakteri yang telah buat preparat ditetesi dengan kristal violet, dibiarkan 60 detik dan dibilas dengan air mengalir, kemudian ditiriskan; (2) ditetesi dengan iodium, dibiarkan 60 detik dan dibilas dengan air mengalir, kemudian ditiriskan; (3) preparat dicuci dengan larutan alkohol-aseton selama 15 sampai 30 detik; (4) ditetesi safranin selama 60 detik kemudian dibilas dan dikeringkan; (5) dilihat dibawah mikroskop dengan perbesaran 100x.

\section{Uji Katalase}

Larutan $\mathrm{H}_{2} \mathrm{O}_{2} 3 \%$ diteteskan 1 tetes di atas object glass kemudian ambil 1 ose koloni bakteri dari media VJA (Vogel Johnson Agar), lalu amati adanya gelembung gas yang menunjukkan hasil positif. 


\section{Uji Koagulase}

Larutan plasma citrate diteteskan 1 tetes kemudian tambahkan 1 tetes suspensi bakteri lalu diamati secara mikroskop dengan melihat ada atau tidaknya penggumpalan yang menunjukkan hasil positif.

\section{Pembuatan suspensi bakteri}

Isolat bakteri dari media VJA (Vogel Johnson Agar) diinokulasikan pada media cair BHI (Brain Heart Infuction) kemudian diinkubasi selama 24 jam. Kekeruhan yang terjadi pada media BHI di-

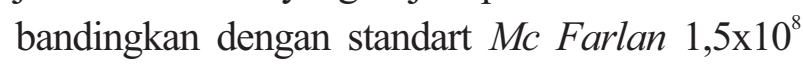
$\mathrm{cfu} / \mathrm{ml}$.

\section{Uji Sensitivitas}

Pengujian dilakukan secara difusi dengan cakram Kirby-Bauer. (1) medium Mueller Agar (MHA) yang telah dicairkan dituang ke dalam cawan petri steril dan ditunggu memadat. (2) kapas lidi steril dimasukkan dalam medium Braint Heart Infusion (BHI) yang mengandung biakan Staphylococcus aureus kemudian goreskan ke medium Mueller Hinton Agar (MHA) dengan metode perataan (Spread Plate Method) dan didiamkan selama 10 menit pada suhu kamar agar suspensi biakan terdifusi ke dalam media. (3) cakram antibiotik diletakkan pada medium Mueller Hinton Agar (MHA) dengan jarak yang sama. (4) medium Mueller Hinton Agar (MHA) diinkubasi pada suhu $37{ }^{\circ} \mathrm{C}$ selama 24 jam dan diukur diameter zona bening yang terbentuk sekitar cakram. Hasil pengukuran kemudian dibandingkan dengan tabel Clinical and Laboratory Standards Institute (CLSI) dan digolongkan menjadi susceptible, intermediate dan resistance.

\section{Hasil dan Pembahasan \\ Isolasi bakteri}

Hasil isolasi pada media VJA (Vogel Johnson Agar) menunjukkan bahwa dari 30 sampel darah pasien sepsis terdapat 16 sampel yang membentuk koloni berwarna hitam dan di sekitar koloni berwarna kuning. Koloni yang berwarna hitam ini disebabkan oleh kemampuan dari Staphylococcus aureus dalam mereduksi kalium tellurit menjadi metallic tellurium sedangkan pembentukkan warna kuning di sekitar koloni disebabkan karena Staphylococcus aureus mampu memfermentasikan manitol menjadi asam, dimana phenol red sebagai indikator dalam suasana asam akan merubah warna media dari merah menjadi kuning (Gambar 1).

\section{Identifikasi bakteri Mikroskopis}

Pewarnaan Gram dari 16 sampel yang diduga positif menunjukkan bakteri Staphylococcus aureus Hal ini disebabkan karena bakteri Staphylococcus aureus tergolong bakteri Gram positif, dimana pada pengecatan Gram akan menghasilkan warna ungu (Gambar 2).

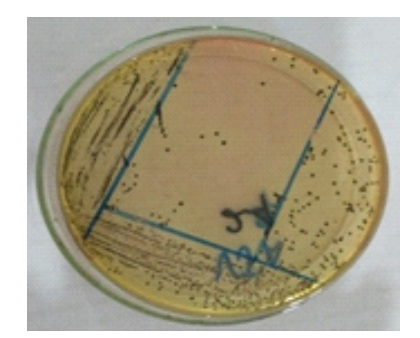

Gambar 1. Medium VJA (Vogel Johnson Agar) yang menunjukkan hasil positif Staphylococcus aureus.

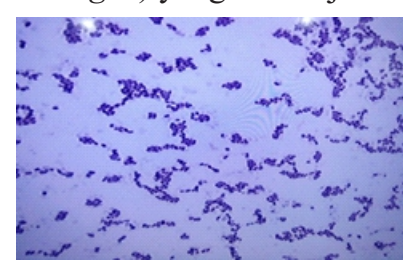

Gambar 2. Hasil pengecatan Gram bakteri Staphyloccoccus aureus perbesaran 100x 


\section{Uji katalase}

Pengujian selanjutnya yaitu uji katalase. Uji katalase merupakan uji yang digunakan untuk membedakan spesies Staphylococcus sp. dan Streptococcus $s p$. Uji katalase juga berguna dalam mengidentifikasi kelompok bakteri yang dapat menghasilkan katalase sehingga dapat dibedakan antara bakteri aerob dan anaerob (Nazhifah dan Darwin 2013). Hasil positif ditunjukkan pada 16 isolat yang diduga Staphylococcus aureus dengan terbentuknya gelembung gas (buih) di sekitar koloni bakteri (Gambar 3).

\section{Uji koagulase}

Uji penegasan setelah uji mikroskopis dan uji katalase adalah uji koagulase. Uji koagulase bertujuan untuk mengetahui kemampuan bakteri menghasilkan enzim koagulase. Uji koagulase juga digunakan untuk menunjukkan sifat virulensi bakteri Staphyloccoccus aureus yaitu dapat melindungi dirinya dari fagositosis dan menghalangi kerja sistem imunitas inang (Radji 2010). Hasil positif ditunjukkan pada 16 isolat yang diduga Staphyloccoccus aureus dengan terbentuknya koagulasi (gumpalan) yang diamati dibawah mikroskop (Gambar 4).

Hasil identifikasi menunjukkan bahwa 16 sampel darah pasien sepsis positif Staphylococcus aureus (53\%). Hasil identifikasi dari 16 sampel darah pasien sepsis yang diduga positif Staphylococcus aureus ditunjukkan pada Tabel 1.

\section{Uji sensitivitas}

Hasil uji sensitivitas Staphylococcus aureus

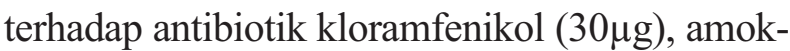
sisilin $(25 \mu \mathrm{g})$, vankomisin $(30 \mu \mathrm{g})$, tetrasiklin $(30 \mu \mathrm{g})$, eritromisin $(15 \mu \mathrm{g})$ dan linezolid $(30 \mu \mathrm{g})$ yang telah dibandingkan dengan tabel Clinical and Laboratory Standards Institute (CLSI) .

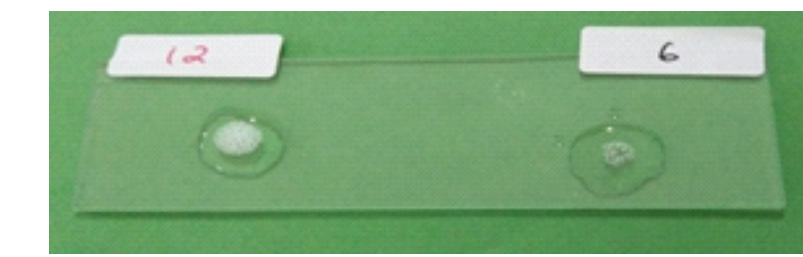

Gambar 3. Hasil uji katalase positif Staphyloccoccus aureus

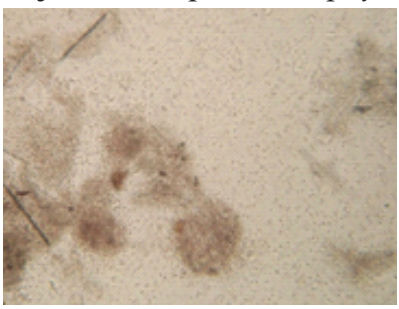

Gambar 4. Hasil uji koagulase positif Staphyloccoccus aureus secara mikroskopis

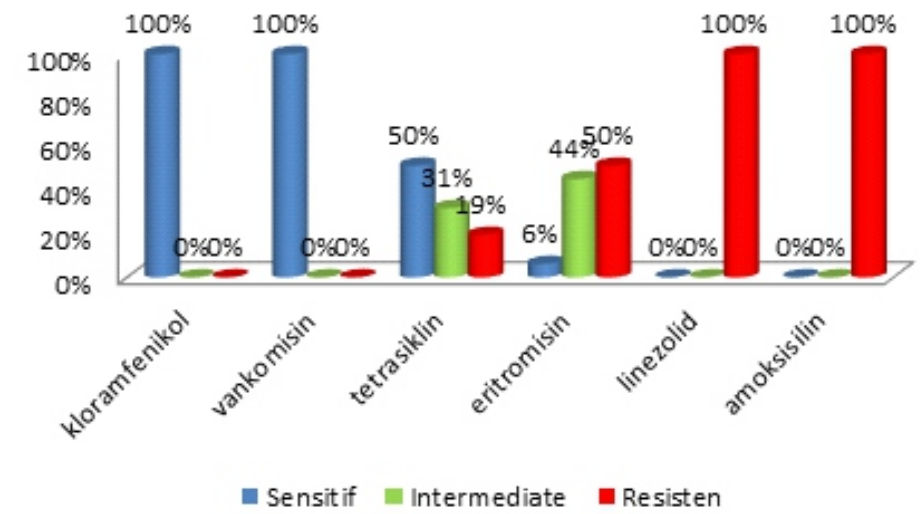

Gambar 5. Hasil persentase tingkat sensitivitas isolat Staphylococcus aureus terhadap antibiotik kloramfenikol, amoksisilin, vankomisin, tetrasiklin, eritromisin dan linezolid. 
Tabel 1. Hasil identifikasi 16 sampel darah pasien sepsis diduga positif Staphylococcus aureus

\begin{tabular}{|c|c|c|c|c|c|}
\hline \multirow[b]{2}{*}{ No. } & \multirow{2}{*}{$\begin{array}{c}\text { No. } \\
\text { Sampel }\end{array}$} & \multicolumn{3}{|c|}{ Identifikasi } & \multirow[b]{2}{*}{ Kesimpulan } \\
\hline & & Mikroskopis & Uji Katalase & $\begin{array}{c}\text { Uji } \\
\text { Koagulase }\end{array}$ & \\
\hline 1 & 764 D & $\begin{array}{c}\text { Bentuk bulat } \\
\text { bergerombol } \\
\text { warna ungu }\end{array}$ & $\begin{array}{c}\text { Terbentuk } \\
\text { gelembung } \\
\text { udara } \\
\end{array}$ & $\begin{array}{l}\text { Terdapat } \\
\text { gumpalan }\end{array}$ & $\begin{array}{l}\text { Positif } \\
\text { Staphyloccoccus } \\
\text { aureus }\end{array}$ \\
\hline 2 & 748 D & $\begin{array}{c}\text { Bentuk bulat } \\
\text { bergerombol } \\
\text { warna ungu }\end{array}$ & $\begin{array}{c}\text { Terbentuk } \\
\text { gelembung } \\
\text { udara } \\
\end{array}$ & $\begin{array}{l}\text { Terdapat } \\
\text { gumpalan }\end{array}$ & $\begin{array}{l}\text { Positif } \\
\text { Staphyloccoccus } \\
\text { aureus }\end{array}$ \\
\hline 3 & $277 \mathrm{D}$ & $\begin{array}{c}\text { Bentuk bulat } \\
\text { bergerombol } \\
\text { warna ungu }\end{array}$ & $\begin{array}{c}\text { Terbentuk } \\
\text { gelembung } \\
\text { udara } \\
\end{array}$ & $\begin{array}{l}\text { Terdapat } \\
\text { gumpalan }\end{array}$ & $\begin{array}{l}\text { Positif } \\
\text { Staphyloccoccus } \\
\text { aureus }\end{array}$ \\
\hline 4 & $228 \mathrm{D}$ & $\begin{array}{c}\text { Bentuk bulat } \\
\text { bergerombol } \\
\text { warna ungu }\end{array}$ & $\begin{array}{c}\text { Terbentuk } \\
\text { gelembung } \\
\text { udara }\end{array}$ & $\begin{array}{l}\text { Terdapat } \\
\text { gumpalan }\end{array}$ & $\begin{array}{l}\text { Positif } \\
\text { Staphyloccoccus } \\
\text { aureus }\end{array}$ \\
\hline 5 & $236 \mathrm{D}$ & $\begin{array}{l}\text { Bentuk bulat } \\
\text { bergerombol } \\
\text { warna ungu }\end{array}$ & $\begin{array}{c}\text { Terbentuk } \\
\text { gelembung } \\
\text { udara }\end{array}$ & $\begin{array}{l}\text { Terdapat } \\
\text { gumpalan }\end{array}$ & $\begin{array}{l}\text { Positif } \\
\text { Staphyloccoccus } \\
\text { aureus }\end{array}$ \\
\hline 6 & $276 \mathrm{D}$ & $\begin{array}{l}\text { Bentuk bulat } \\
\text { bergerombol } \\
\text { warna ungu }\end{array}$ & $\begin{array}{c}\text { Terbentuk } \\
\text { gelembung } \\
\text { udara }\end{array}$ & $\begin{array}{l}\text { Terdapat } \\
\text { gumpalan }\end{array}$ & $\begin{array}{l}\text { Positif } \\
\text { Staphyloccoccus } \\
\text { aureus }\end{array}$ \\
\hline 7 & $333 \mathrm{D}$ & $\begin{array}{l}\text { Bentuk bulat } \\
\text { bergerombol } \\
\text { warna ungu }\end{array}$ & $\begin{array}{c}\text { Terbentuk } \\
\text { gelembung } \\
\text { udara }\end{array}$ & $\begin{array}{l}\text { Terdapat } \\
\text { gumpalan }\end{array}$ & $\begin{array}{l}\text { Positif } \\
\text { Staphyloccoccus } \\
\text { aureus }\end{array}$ \\
\hline 8 & $425 \mathrm{D}$ & $\begin{array}{l}\text { Bentuk bulat } \\
\text { bergerombol } \\
\text { warna ungu }\end{array}$ & $\begin{array}{c}\text { Terbentuk } \\
\text { gelembung } \\
\text { udara }\end{array}$ & $\begin{array}{l}\text { Terdapat } \\
\text { gumpalan }\end{array}$ & $\begin{array}{l}\text { Positif } \\
\text { Staphyloccoccus } \\
\text { aureus }\end{array}$ \\
\hline 9 & $359 \mathrm{D}$ & $\begin{array}{l}\text { Bentuk bulat } \\
\text { bergerombol } \\
\text { warna ungu }\end{array}$ & $\begin{array}{c}\text { Terbentuk } \\
\text { gelembung } \\
\text { udara } \\
\end{array}$ & $\begin{array}{l}\text { Terdapat } \\
\text { gumpalan }\end{array}$ & $\begin{array}{l}\text { Positif } \\
\text { Staphyloccoccus } \\
\text { aureus }\end{array}$ \\
\hline 10 & $292 \mathrm{D}$ & $\begin{array}{l}\text { Bentuk bulat } \\
\text { bergerombol } \\
\text { warna ungu }\end{array}$ & $\begin{array}{c}\text { Terbentuk } \\
\text { gelembung } \\
\text { udara }\end{array}$ & $\begin{array}{l}\text { Terdapat } \\
\text { gumpalan }\end{array}$ & $\begin{array}{l}\text { Positif } \\
\text { Staphyloccoccus } \\
\text { aureus }\end{array}$ \\
\hline 11 & $455 \mathrm{D}$ & $\begin{array}{l}\text { Bentuk bulat } \\
\text { bergerombol } \\
\text { warna ungu }\end{array}$ & $\begin{array}{c}\text { Terbentuk } \\
\text { gelembung } \\
\text { udara } \\
\end{array}$ & $\begin{array}{l}\text { Terdapat } \\
\text { gumpalan }\end{array}$ & $\begin{array}{l}\text { Positif } \\
\text { Staphyloccoccus } \\
\text { aureus }\end{array}$ \\
\hline 12 & $405 \mathrm{D}$ & $\begin{array}{l}\text { Bentuk bulat } \\
\text { bergerombol } \\
\text { warna ungu } \\
\end{array}$ & $\begin{array}{c}\text { Terbentuk } \\
\text { gelembung } \\
\text { udara } \\
\end{array}$ & $\begin{array}{l}\text { Terdapat } \\
\text { gumpalan }\end{array}$ & $\begin{array}{l}\text { Positif } \\
\text { Staphyloccoccus } \\
\text { aureus }\end{array}$ \\
\hline 13 & $295 \mathrm{D}$ & $\begin{array}{l}\text { Bentuk bulat } \\
\text { bergerombol } \\
\text { warna ungu }\end{array}$ & $\begin{array}{l}\text { Terbentuk } \\
\text { gelembung } \\
\text { udara }\end{array}$ & $\begin{array}{l}\text { Terdapat } \\
\text { gumpalan }\end{array}$ & $\begin{array}{l}\text { Positif } \\
\text { Staphyloccoccus } \\
\text { aureus }\end{array}$ \\
\hline 14 & $457 \mathrm{D}$ & $\begin{array}{l}\text { Bentuk bulat } \\
\text { bergerombol } \\
\text { warna ungu }\end{array}$ & $\begin{array}{c}\text { Terbentuk } \\
\text { gelembung } \\
\text { udara } \\
\end{array}$ & $\begin{array}{l}\text { Terdapat } \\
\text { gumpalan }\end{array}$ & $\begin{array}{l}\text { Positif } \\
\text { Staphyloccoccus } \\
\text { aureus }\end{array}$ \\
\hline 15 & $485 \mathrm{D}$ & $\begin{array}{l}\text { Bentuk bulat } \\
\text { bergerombol } \\
\text { warna ungu }\end{array}$ & $\begin{array}{c}\text { Terbentuk } \\
\text { gelembung } \\
\text { udara } \\
\end{array}$ & $\begin{array}{l}\text { Terdapat } \\
\text { gumpalan }\end{array}$ & $\begin{array}{l}\text { Positif } \\
\text { Staphyloccoccus } \\
\text { aureus }\end{array}$ \\
\hline 16 & $404 \mathrm{D}$ & $\begin{array}{l}\text { Bentuk bulat } \\
\text { bergerombol } \\
\text { warna ungu }\end{array}$ & $\begin{array}{c}\text { Terbentuk } \\
\text { gelembung } \\
\text { udara }\end{array}$ & $\begin{array}{l}\text { Terdapat } \\
\text { gumpalan }\end{array}$ & $\begin{array}{l}\text { Positif } \\
\text { Staphyloccoccus } \\
\text { aureus }\end{array}$ \\
\hline
\end{tabular}

Berdasarkan Gambar 5 menunjukkan bahwa 16 isolat Staphyloccoccus aureus 100\% sensitif terhadap antibiotik kloramfenikol. Kloramfenikol bekerja dengan menghambat sintesis protein kuman. Obat ini terikat pada ribosom subunit 50S dan menghambat enzim peptidil transferase sehingga ikatan peptida tidak terbentuk pada proses sintesis protein kuman (Gunawan 2007).

Staphyloccoccus aureus 100\% sensitif terhadap antibiotik vankomisin. Vankomisin efektif melawan bakteri Gram positif. Vankomisin membunuh bakteri dengan cara menghambat sintesis dinding sel bakteri. Indikasi dari antibiotik vankomisin adalah septikemia dan endokarditis yang 
disebabkan oleh Staphylococcus, Streptococcus, atau Enterococcus.

Penelitian ini sesuai dengan penelitian yang dilakukan oleh Patil dan Pratibha (2016) yang berjudul Bacterial Profile and Resistance Pattern of Bacterial Isolates from Blood Culture - a five year study in Tertiary Care Teaching Hospital menunjukkan bahwa dari 13 sampel (27,66\%) yang positif bakteri Staphylococcus aureus 100\% sensitif terhadap antibiotik vankomisin.

Staphylococcus aureus 50\% sensitif, 31\% intermediate dan 19\% resisten terhadap antibiotik tetrasiklin. Tetrasiklin merupakan antibiotik yang digunakan untuk mengobati infeksi Gram positif maupun Gram negatif serta beberapa protozoa. Tetrasiklin masuk ke dalam sel bakteri Gram negatif dan Gram positif untuk menghambat sintesis protein (Radji, 2014).

Staphylococcus aureus $6 \%$ sensitif, 44\% intermediate dan 50\% resisten terhadap antibiotik eritromisin. Eritromisin adalah obat yang efektif terhadap beberapa bakteri dan digunakan pada pasien yang alergi terhadap penisilin. Eritromisin mengikat 50S ribosom pada bakteri Gram positif.

Staphylococcus aureus 100\% resisten terhadap antibiotik linezolid. Linezolid efektif untuk mengatasi bakteri Gram positif yang resisten terhadap banyak obat, seperti Staphylococcus aureus metisilin-resisten (MRSA) dan Staphylococcus aureus yang resisten vankomisin (VRSA). Mekanisme aksi dari linezolid adalah mampu menghambat sintesis protein bakteri dengan cara menghambat pembentukkan kompleks inisiasi 70S (Radji, 2014).

Staphylococcus aureus 100\% resisten terhadap antibiotik amoksisilin. Amoksisilin adalah antibiotika golongan $\beta$-laktam dengan spektrum yang luas (Fitriani, 2010). Amoksisilin bekerja dengan cara menghambat sintesis peptidoglikan dinding sel bakteri.

Penelitian ini sesuai dengan penelitian pola resistensi bakteri dari kultur darah yang dilakukan di Laboratorium Mikrobiologi Klinik Fakultas Kedokteran Universitas Indonesia pada tahun
2001-2006 terhadap antibiotik golongan penisilin bahwa Staphylococcus aureus mengalami peningkatan resistensi terhadap antibiotik amoksisilin (Al Hanif, 2009).

\section{Kesimpulan}

1. Hasil menunjukkan bahwa dari 30 sampel terdapat 16 sampel positif Staphylococcus aureus $(53 \%)$.

2. Uji sensitivitas Staphyloccoccus aureus $100 \%$ sensitif terhadap antibiotik kloramfenikol dan vankomisin, 50\% sensitif, 31\% intermediate dan $19 \%$ resisten terhadap antibiotik tetrasiklin, $6 \%$ sensitif, 44\% intermediate dan 50\% resisten terhadap antibiotik eritromisin dan $100 \%$ resisten terhadap antibiotik amoksisilin dan linezolid.

\section{SARAN}

1. Perlu dilakukan penelitian terhadap antibiotik lain yang dapat digunakan dalam pengobatan sepsis selain antibiotik amoksisilin dan linezolid.

2. Perlu dilakukan penelitian terhadap bakteri patogen lainnya.

\section{DAFTAR PUSTAKA}

Al Hanif, M. S. 2009. Pola Resistensi Bakteri Dari Kultur Darah Terhadap Golongan Penisilin Di Laboratorium Mikrobiologi Klinik Fakultas Kedokteran Universitas Indonesia Tahun 2001-2006. [Skripsi]. Jakarta: Fakultas Kedokteran, Universitas Indonesia.

Artero, A., Zaragoza, R., Nogueira, J. M. 2012. Epidemiology of Severe Sepsis and Septic Shock R. Fernandez. Croatia: In Tech.

Bennet, N. J. 2008. Bakteremia. [online]. (www.emedicine.com, diakses pada 18 Desember 2015).

Brooks, G. F., Carroll, K. C., Butel, J. S., Morse, S. A. 2010. Jawetz, melnick, and adelberg's. Medical Microbiology. 25th edition. USA: McGraw-Hill Companies; 4.

Fitriani, S. 2010. Penetapan Kadar Amoksisilin dalam Kaplet Omemox secara Spektrofotometer Ultraviolet di PT. Mutifa Industri Farmasi Medan [Skripsi]. Medan: Fakultas Farmasi, Universitas Sumatra Utara.

Gillani, W. S., Sulaiman, A. S., and Nejad, F. B. 2009. Antibiotic Resistance and Therapeutic Management of Sepsis in a Malaysian public Hospital, Australasian. Medical Journal. 1 (14), 244-245.

Gunawan, S. G. 2007. Farmakologi dan Terapi. Edisi 5. Jakarta: Gaya Baru.

Hoyert, D. L., Arias, E., Smith, B. L., Murphy, S. L., Kochanek, K. D. 2001 Deaths: Final Data for 1999. National Vital Statistics Report: 49.

Irawan, I. D. 2010. Atasi Sepsis dengan Kombinasi Antibiotik. Artikel. [online]. 30 Juli 2010. (http://www.edisicetak. joglosemar.co/berita/atasi-sepsis-dengan-kombinasi- 
antibiotik-21264.html, diakses 20 Desember 2015).

James, M. J., Naeem, A. A., and Edward, A. 2005. Year in Review in Critical Care, 2004: Sepsis and Multi-Organ Failure. Crit Care. 9(4): 409-13.

Nasronuddin. 2011. Penyakit Infeksi di Indonesia Solusi Kini dan Mendatang. Edisi 2. Universitas Airlangga.

Nazhifah, R. dan Darwin D. 2013. Uji Sensitivitas Isolate Bakteri dari Pasien Luka Bakar di Bangsal Luka Bakar RSUP DR. M. Djamil Padang. Prosiding Seminar Nasional Perkembangan Terkini Sains Farmasi dan Klinik III. p 216. ISSN: 2339-2592.

Patil, A. A. dan Pratibha J. D. 2016. Bacterial Profile and Resistance Pattern of Bacterial Isolates from Blood Culture - a Five Year Study in Tertiary Care Teaching Hospital. European Journal Of Pharmaceutical And Medical Research, Vol 3(4); 373-377. ISSN 2394-3211.
Pristianingrum, S., Dharmawibawa, I. D., Zainiati, B. L. 2012. Daya Hambat Infusa Kelopak Bunga Rosella secara In Vitro terhadap Pertumbuhan Bakteri Staphylococcus aureus Resisten Amoksisilin (MRSA). Jurnal Kesehatan Prima Vol. 6 No. 1 Februari 2012.

Radji, M. 2009. Buku Ajar Mikrobiologi. Jakarta: Penerbit Buku Kedokteran EGC.

Radji, M. 2010. Buku Ajar Mikrobiologi: Panduan Mahasiswa Farmasi dan Kedokteran. Jakarta: EGC.

Radji, M. 2014. Mekanisme Aksi Molekuler Antibiotic dan Kemoterapi. Jakarta: EGC.

SWAB, 2010, SWAB Guidelines for Antibacterial Antibacterial Therapy of Adult Patients with Sepsis, 1-86, Netherland, Stichting Werkgroep Antibioticabeled.

Wickner W. dan Schekman R. 2005. Protein Translocation Across Biological Membranes. Science 310: 1456-1452. 